\title{
Sleuthing cryptic Chromodorids (Mollusca, Nudibranchia): adding to Philippine marine biodiversity
}

\section{Terrence M. Gosliner}

\begin{abstract}
The Verde Island Passage of the Philippines is renowned for its rich marine biodiversity and heterobranch mollusks are demonstrable models of that species richness of the region. Chromodorid nudibranchs represent a particularly rich taxon, with species of Chromodoris being one of the most iconic and abundant taxa in shallow water coral reef environments. Despite being one of the best documented clades of nudibranch mollusks, recent work has shown that numerous cryptic and pseudocryptic species are abundant in the waters of the Coral Triangle region. This paper reviews the species richness and distribution of Chromodoris species in the Philippines and provides a description of a new species of Chromodoris from the region. Chromodoris alcalai Gosliner, n. sp. is named to honor Dr. Angel Alcala's $90^{\text {th }}$ birthday and his pioneering contributions to preserving the marine biodiversity of the Philippines. This species is most similar externally to C. dianae Gosliner and Behrens, 1998, with which it was erroneous lumped. Distinctness of molecular data, external morphology and coloration, and internal anatomical features clearly distinguish these two species.
\end{abstract}

Keywords: systematics, Nudibranchia, coral reefs, Indo-Pacific, Coral Triangle

\section{Introduction}

Chromodorid nudibranchs are brightly colored shell-less slugs that are ubiquitous residents of shallow-water and mesophotic coral reefs in the Indo-Pacific biotic region (Rudman, 1984; Gosliner et al., 2018). Generic boundaries within the Chromodorididae have been re-evaluated based on new phylogenetic relationships determined by molecular data (Wilson \& Lee, 2005; Turner \& Wilson, 2008; Johnson \& Gosliner, 2012). Since then, Matsuda \& Gosliner (2018) have described new species of Glossodoris and Doriprismatica from the Philippines and elsewhere. Epstein et al. (2018) provided an updated molecular phylogeny of Hypselodoris, that included descriptions of 17 new species from the Indo-Pacific, including 10 new species from the Philippines. Perhaps the most surprising result was the recent work by Layton et al. (2018) on Indo-Pacific species of Chromodoris. Subsequently, Tibiriçá et

Department of Invertebrate Zoology and Geology, California Academy of Sciences, 55 Music Concourse Drive, San Francisco, CA 94118, USA

*Corresponding email: tgosliner@,calacademy.org

Date Submitted: 30 July 2019

Date Accepted: 09 December 2020 al. (2020) described an additional two new species of Chromodoris from East Africa, C. celinae Tibiriçá, Pola, Ortigosa \& Cervera, 2020 and C. helium Tibiriçá, Pola, Ortigosa \& Cervera, 2020.

Chromodoris is the most well-studied genus within the family and Layton et al. (2018) recognized 17 new species, of which 5 were found from the Philippines. Two of these species have been described recently (Bonomo \& Gosliner, 2020) as $C$. quagga Bonomo \& Gosliner, 2020 and C. balat Bonomo \& Gosliner, 2020. An additional species, not recognized by Layton et. al. (2018), was identified by Bonomo \& Gosliner (2020) and described as C. kalawakan Bonomo \& Gosliner, 2020. Layton et al. (2018) also denoted remarkable polymorphism in color pattern in Chromodoris that indicated regional convergence in some species. One of these undescribed species from the Philippines was previously considered as a color variant of Chromodoris dianae Gosliner \& Behrens, 1998, but has been shown to represent a distinct lineage based upon molecular phylogeny (Layton et al., 2018). Further complicating the situation is the separation of the type material of $C$. dianae, which includes more than one species, plus additional confusion in the literature as to the true identity of $C$. dianae and the new species described here. The focus of this paper is to formally describe this species and to review the diversity of species of Chromodoris within the Philippines. 


\section{Materials and Methods}

Specimens of the new species described in this study were collected on several field trips to the Philippines by scuba diving. All the specimens here studied are currently located at the California Academy of Sciences, Department of Invertebrate Zoology and Geology in San Francisco (CASIZ), and the National Museum of the Philippines (NMP). Features of living animals were recorded in the field and from photographs. The specimens were preserved in Bouin's fixative, $75 \%$ or $95 \%$ EtOH. Morphological analyses of rhinophores, gill, radula, buccal mass, and reproductive structures were used to verify placement in the tree and distinguish the new species from others. Specimens were dissected using a Nikon SMZ-U dissecting scope to extract the buccal mass, mantle glands, and reproductive structures for each nudibranch. The buccal mass was placed in a $10 \%$ solution of $\mathrm{NaOH}$ for about $24 \mathrm{~h}$. The jaws and radulae were rinsed in deionized water and mounted on glass coverslips. After the jaws and radulae were dry, the cover slip was mounted on a scanning electron microscope (SEM) stub for observation. The samples were covered with gold/ palladium using a Cressington 108 Auto vacuum sputter coater. Imaging of the jaws, radulae, and teeth were done on a Hitachi SU3500 SEM. The reproductive structures were drawn using a camera lucida drawing attachment on the Nikon SMZ-U dissecting scope. The external features were examined directly, by photographs, or by literature review depending on availability of specimens. Specimens and dissected structures were deposited at CASIZ and the holotype will be sent to NMP.

\section{Nomenclatural Acts}

This published work and the nomenclatural acts it contains have been registered in ZooBank, the online registration system for the ICZN. The ZooBank LSIDs (Life Science Identifiers) can be resolved and the associated information viewed through any standard web browser by appending the LSID to the prefix "http://zoobank.org/". The LSID for this publication is urn: lsid:zoobank.org:pub:2C771B40-87B3-4B4A-AC22-

81FA6EA75FF6

\section{Results}

Species Description:

Family Chromodorididae Bergh, 1891

Chromodoris Alder \& Hancock, 1855

Chromodoris alcalai Gosliner, 2020, sp. nov.

(Figures 1a-d - 4)

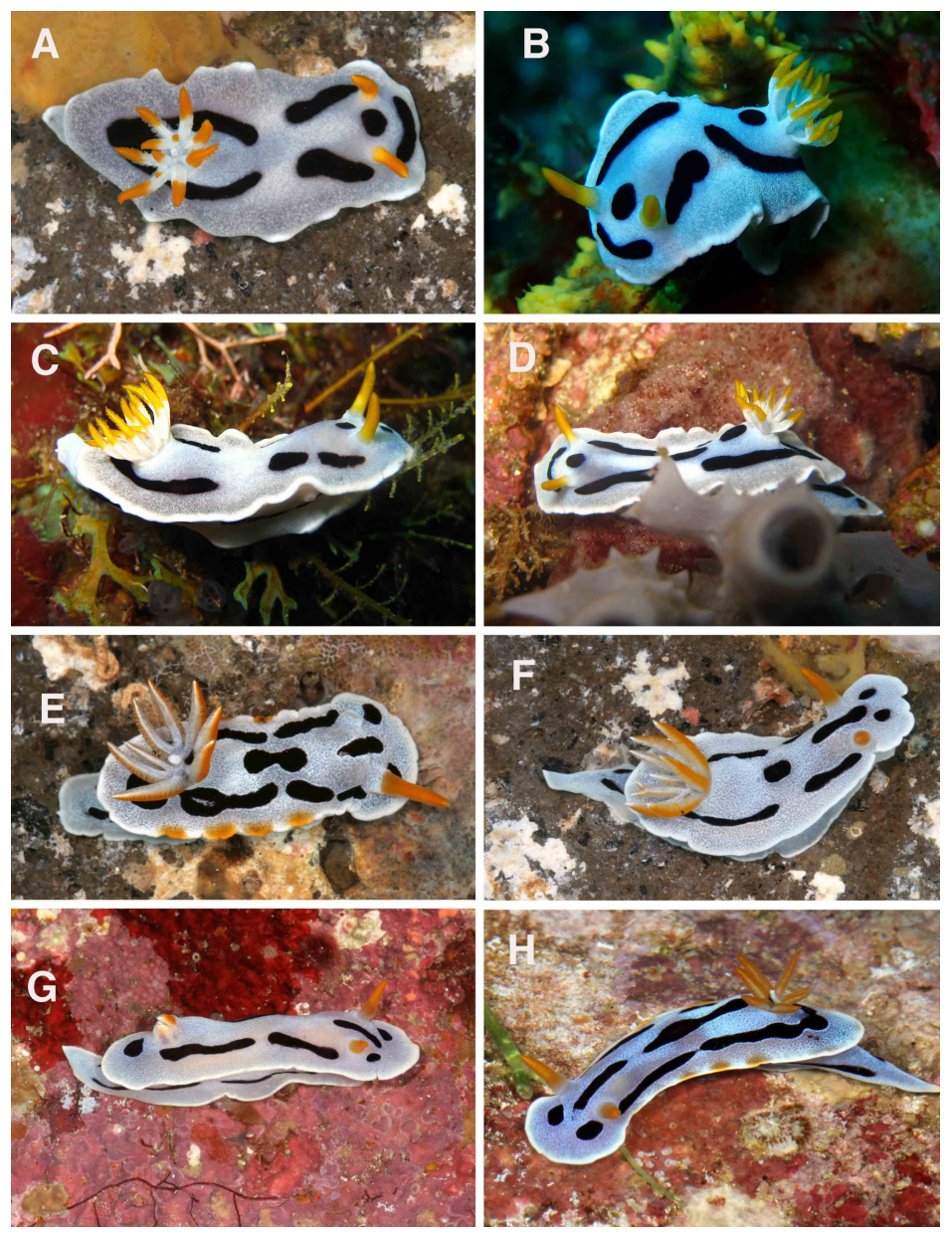

Figure 1. Living animals. a-d Chromodoris alcalai n. sp. a. Holotype, NMP 041295, Kirby's Rock, Tingloy, Batangas, Philippines. b. C. alcalai, Kirby's Rock, Tingloy, Batangas, Philippines, 11 March, 2019. c. C. alcalai, Agajota Reef, Tingloy, Batangas, Philippines, 20 May, 2009. d. C. alcalai, Kirby's Rock, Tingloy, Batangas, Philippines, 18 May, 2010. e-h. Chromodoris dianae Gosliner \& Behrens, 1998. e. CASIZ 177241, Kirby's Rock, Tingloy, Batangas, Philippines, 16 March 2008. f. CASIZ 177243, Kirby's Rock, Tingloy, Batangas, Philippines, 16 March 2008. g. CASIZ 182289, Blue Hole, n. tip Tablas Island, Romblon, Philippines, 19 February, 2010. h. CASIZ 200677, Binicas, Lubang, Lubang Island, Mindoro Occidental, Philippines, 30 May 2014. all photos by T. Gosliner.

LSID url: urn:lsid:zoobank.org:act:EF55DF98-5693-434E-8C48 -D93C552BFDA0

Chromodoris dianae Gosliner \& Behrens: 1998, misidentification, in part, Gosliner et al., 2008: 207, misidentification, in part, lower middle right photo, lower left photo. Gosliner et al., 2015: 211, misidentification, in part, upper right photo, upper middle right photo. Gosliner et al., 2018: 137, misidentification, middle two photos. 
Type material:

Holotype: NMP 041295 (formerly CASIZ 177242, molecular voucher in Layton et al., 2018), Kirby's Rock, Tingloy, Batangas, Luzon, Philippines, $13.6911^{\circ} \mathrm{N}$ Lat., $120.8414^{\circ}$ E Long., 16 Mar 2008, $31.2 \mathrm{~m}$ depth, collected by $\mathrm{T}$. Gosliner et al.

Paratypes: Paratypes: CASIZ 083686, (formerly paratypes of $C$. dianae), three specimens, one dissected, Kirby's Rock, Tingloy, Maricaban Island, Philippines, $23 \mathrm{~m}$ depth, 18 February 1992, T. M. Gosliner. CASIZ 103789, (formerly paratypes of $C$. dianae), two specimens, Cathedral Rock, Mabini, Batangas Province, Luzon, Philippines, $22 \mathrm{~m}$ depth, 25 February 1995, T. M. Gosliner. CASIZ 231159 (ex 086002), (formerly paratype of $C$. dianae), one specimen, $\mathrm{N}$ end of Ligpo Island, Bauan, Balayan Bay, Batangas, Luzon, Philippines, 26 m depth, 24 March 1993, T. M. Gosliner. CASIZ 076326, (formerly paratype of $C$. dianae), one specimen, $\mathrm{SW}$ corner of North Reef, Tubbataha Reefs, Sulu Sea, Philippines, 909'N, 1 1955'E, 8-16 m depth, 13 March 1984, Antonio J. Ferreira. CASIZ 231160 (ex CASIZ 096278), (formerly paratype of $C$. dianae), one specimen, Kirby's Rock, Caban Island, Tingloy, Maricaban Strait, Batangas, Luzon, 18 m depth, 17 March 1994, T. M. Gosliner. CASIZ 087270, (formerly paratype of $C$. dianae), one specimen, Manado, Celebes Sea, Sulawesi, Indonesia, April 1988, Pauline Fiene-Severns. CASIZ 096266, (formerly paratypes of $C$. dianae), three specimens, Kirby's Rock, Caban Island, Maricaban Strait, Tingloy, Batangas, Philippines, $25 \mathrm{~m}$ depth, 13 March 1994, T. M. Gosliner. CASIZ 076308, (formerly paratypes of $C$. dianae), three specimens, Jessie Beazley Reef, Tubbataha Reefs, Sulu Sea, Philippines, 2-77 m depth, $9^{\circ} 02$ 'N, 11949'E, 15 March 1984, Antonio J. Ferreira. CASIZ 076288, three specimens, Filomena Shoals, Cuyo Island, Sulu Sea, Philippines, $10^{\circ} 40^{\prime} \mathrm{N}, 120^{\circ} 46^{\prime} \mathrm{E}$, 25-33 m depth, 10 March 1984, Antonio J. Ferreira. CASIZ 110465, (formerly paratype of $C$. dianae), one specimen, Kirby's Rock, Caban Island, Maricaban Strait, Philippine Islands, $25 \mathrm{~m}$ depth, 19 April 1997, D. W. Behrens. CASIZ 173528, 1 specimen, edge of reef platform and slope, Black Forest, Balicasag Island, Bohol, Philippines, $22 \mathrm{~m}$ depth, June 4 2004, T. Gosliner. CASIZ 173530, one specimen, Panglao, Bohol, Philippines, June 21 2004, T. Gosliner, Y. Camacho, J. Templado, M. Malaquias, M. Poddubetskaia. CASIZ 173749, one specimen, Bohol Island, Philippines, $5 \mathrm{~m}$ depth, 1 September 2003, J. Hinterkircher. CASIZ 176654, 1 specimen, rocks, seagrass, sand and coral patches, Looc, Panglao, Bohol, Philippines, 22 June 2004, T. Gosliner, Y. Camacho, J. Templado, M. Malaquias, M. Poddubetskaia. CASIZ 176674, 1 specimen, sand ledge with coral patches, reef wall, Cathedral, Balicasag Island, Bohol, Philippines, $48 \mathrm{~m}$ depth, 5 June 2004,
T. Gosliner, Y. Camacho, J. Templado, M. Malaquias, M. Poddubetskaia. CASIZ 089007, mixed sand and strewn coral rubble, $1.3 \mathrm{~km}$ ENE of Maeki-zaki, Seragaki Beach, Okinawa, Ryukyu Islands, Japan, 140 ft. depth, 26 30.4' N, 127 52.6' E, 9 September 1992, R. Bolland.

Comparative material of Chromodoris dianae examined:

Holotype, CASIZ 106464, Arthur's Rock, Mabini, Batangas Province, Luzon, Philippines, 17 April, 1996, Jerry Allen. Paratype, CASIZ 76374, 1 specimen, Ilin Point: (S end of Ilin Island), Mindoro, Philippines, $12^{\circ} \mathrm{N}, 121^{\circ} \mathrm{E}, 23 \mathrm{~m}$ depth, 7 March 1984, Antonio J. Ferreira. Paratype, CASIZ 084276, 8 specimens, two dissected, $\mathrm{N}$ end of Ligpo Island, Bauan, Batangas Province, Luzon, Philippines, $21 \mathrm{~m}$ depth, 25 February 1992, T.M. Gosliner and D.W. Behrens. Paratype, CASIZ 84292, 1 specimen, Bus Stop Reef, Balayan Bay, Bauan, Batangas Province, Philippines, $23 \mathrm{~m}$ depth, 11 February 1998, T.M. Gosliner \& D.W. Behrens. Paratypes, CASIZ 86002, 2 specimens, Ligpo Island, Balayan Bay, Bauan, Batangas Province, Luzon, Philippines, 26 m depth, 24 March 1993, T.M. Gosliner. Paratypes, CASIZ 96278, two specimens, Kirby's Rock, Tingloy, Caban Island, Batangas Province, Luzon, Philippines, 18 m depth, 17 March 1994, T.M. Gosliner \& D.W. Behrens. Paratype, CASIZ 110466, 1 specimen, Santa Rosa Island, Cebu Island, Philippines, 25 m depth, 27 April 1997, Nora Ross. Paratype, CASIZ 110467, 1 specimen, Santa Rosa Island, Cebu Island, Philippines, $30 \mathrm{~m}$ depth, 26 April 1997, D. W. Behrens. Molecular voucher (Layton et al., 2018), CASIZ 158686, off Eagle Point Resort, Mabini, Batangas Province, Luzon, Philippines, $20 \mathrm{~m}$ depth, 05 May 2001, T.M. Gosliner. Molecular voucher (Layton et al., 2018), CASIZ 177241, one specimen, Kirby's Rock, Tingloy, Caban Island, Batangas Province, Luzon, Philippines, $31.2 \mathrm{~m}$ depth, 18 March 2008, T.M. Gosliner, A. Valdes, M. Pola, L. Witzel, B. Moore, A. Alejandrino. CASIZ 177243, one specimen, Kirby's Rock, Tingloy, Caban Island, Batangas Province, Luzon, Philippines, 31.2 m depth, 16 March 2008, T.M. Gosliner, A. Valdes, M. Pola, L. Witzel, B. Moore, A. Alejandrino. CASIZ 177244, one specimen, Kirby's Rock, Tingloy, Caban Island, Batangas Province, Luzon, Philippines, $31.2 \mathrm{~m}$ depth, 16 March 2008, .M. Gosliner, A. Valdes, M. Pola, L. Witzel, B. Moore, A. Alejandrino. Molecular voucher (Layton et al., 2018), CASIZ 182289, "Blue Hole", N tip of Tablas Island, Romblon Province, Sibuyan Sea, Philippines, $12.61599^{\circ} \mathrm{N}, 122.25231^{\circ} \mathrm{E}, 30 \mathrm{~m}$ depth, 30 May 2014, T.M. Gosliner. Molecular voucher, CASIZ 200677, one specimen, Binicas, Lubang, Lubang Island, Mindoro Occidental, Philippines, $13.78111^{\circ} \mathrm{N}, 120.10234^{\circ} \mathrm{E}$, 27m depth, 30 May 2014, T.M. Gosliner. 
Type locality: Kirby's Rock, Caban Island, Tingloy, Batangas Province, Philippines, $13.6911^{\circ} \mathrm{N}$ Lat., $120.8414^{\circ} \mathrm{E}$ Long.

Etymology: This species is named Chromodoris alcalai to honor Professor Angel Alcala's $90^{\text {th }}$ birthday and his pioneering contributions to preserve the marine biodiversity of the Philippines.

Geographical Distribution: This species is known from Okinawa, the Philippines, Indonesia, Western Australia and Malaysia (Gosliner et al., 2018; Layton et al., 2018).

\section{Description:}

External morphology: Living animals (Figure 1) are medium to large, with a length of $15-60 \mathrm{~mm}$ and are found at depths from 10 to $30 \mathrm{~m}$. The body is a translucent white or light blue with a dense covering of small opaque white spots, giving the animals a powdery appearance. There is a distinct band of opaque white along the lateral margins of the notum. On the body is a varied pattern of black bands and spots (Fig. 1a-d, Fig. 2). Despite the variation exhibited by specimens (Fig. 2), there are some consistent features in the distribution of black pigment. The black pigment is still well-defined in preserved specimens in addition to photos of living specimens. In more than fifty preserved specimens or photos of living animals, all specimens have a black curved line across the anterior end of the animal followed by two black lines or curved bands extending posteriorly on the outer side of the body, that may be variously angled. All specimens have a u-shaped or v-shaped pigment band that extends posteriorly behind the gill. There are one to three black spots found medially along the body. The 817 unipinnate gill branches are white basally and are orange on the inner and outer surfaces on the outer half of the branch in all 17 specimens examined where the gills were visible. They are arranged in a double spiral fashion (Fig. 8a). The uniformly orange perfoliate rhinophores have 18-24 distinct lamellae (Figs. 1a-d). The posterior end of the foot extends slightly beyond the posterior end of the mantle and is ornamented with a convergence of two black lines and an additional posterior spot in all specimens examined. Black lines are also present along the lateral sides of the mantle. On either side of the mouth there is a pair of digitiform whitish oral tentacles. The underside of the foot and head are translucent white.

Mantle Glands: The mantle glands are subcutaneous around the entire mantle edge, except for the anterior margin anterior to the rhinophores and at the posterior extreme of the body (Fig. 4a). There are approximately 6-7 mantle glands on each side of the mantle. They are slightly yellower in color on the preserved paratypes (CASIZ 083686a, b). The mantle

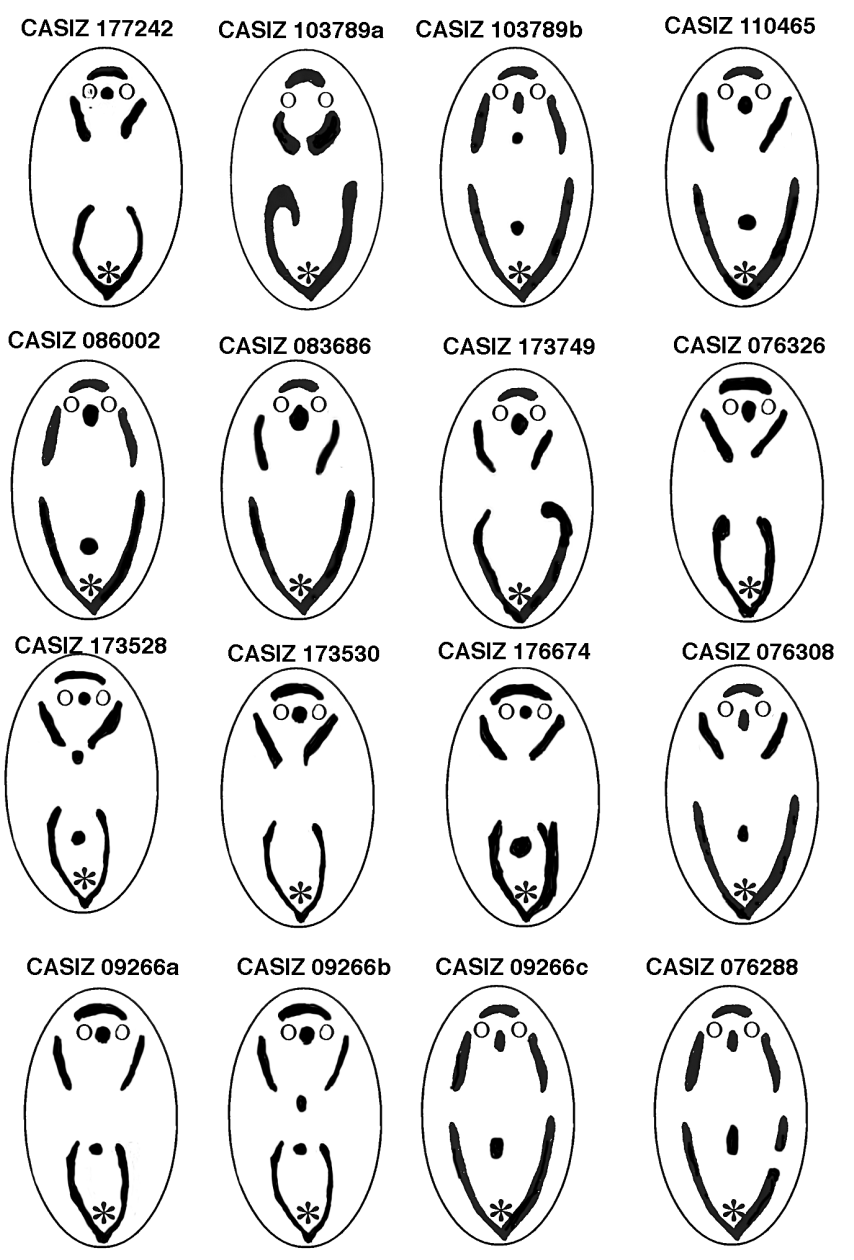

Figure 2. Chromodoris alcalai n. sp., color patterns.

glands are highly ramified in the specimens examined (Fig. 4b).

Buccal mass: The muscular portion of the buccal mass is slightly smaller than the oral tube length. A chitinous labial cuticle is found at the anterior end of the muscular portion with widely-forked, bifurcated jaw elements (Fig, 6f). The radular formula in two paratypes, CASIZ 083686a and CASIZ 083686b are $76 \times 47.1 .47$ and $69 \times 47.1 .47$, respectively (Figs. 6a, b). The rachidian teeth (Fig. 6c), are thin and linear to slightly triangular without a distinct cusp. On either side of the rachidian, the thin inner lateral teeth have 2-3 denticles on the inner side of the primary cusp and 3-4 on the outer side (Fig. 6c). The remaining inner laterals only have denticles on the outer side of the central cusp. The middle lateral teeth have an elongate cutting edge with 4 to 5 acutely pointed denticles (Fig. 6d). The outer lateral teeth are elongate with 4 to 6 more rounded denticles (Fig. 6e).

Reproductive system (Fig. 4c, d): The reproductive system was examined in two paratypes (CASIZ 083686a, CASIZ 083686b). The thin pre-ampullary duct connects the ovotestis with the wider elongate somewhat curved ampulla. The ampulla 


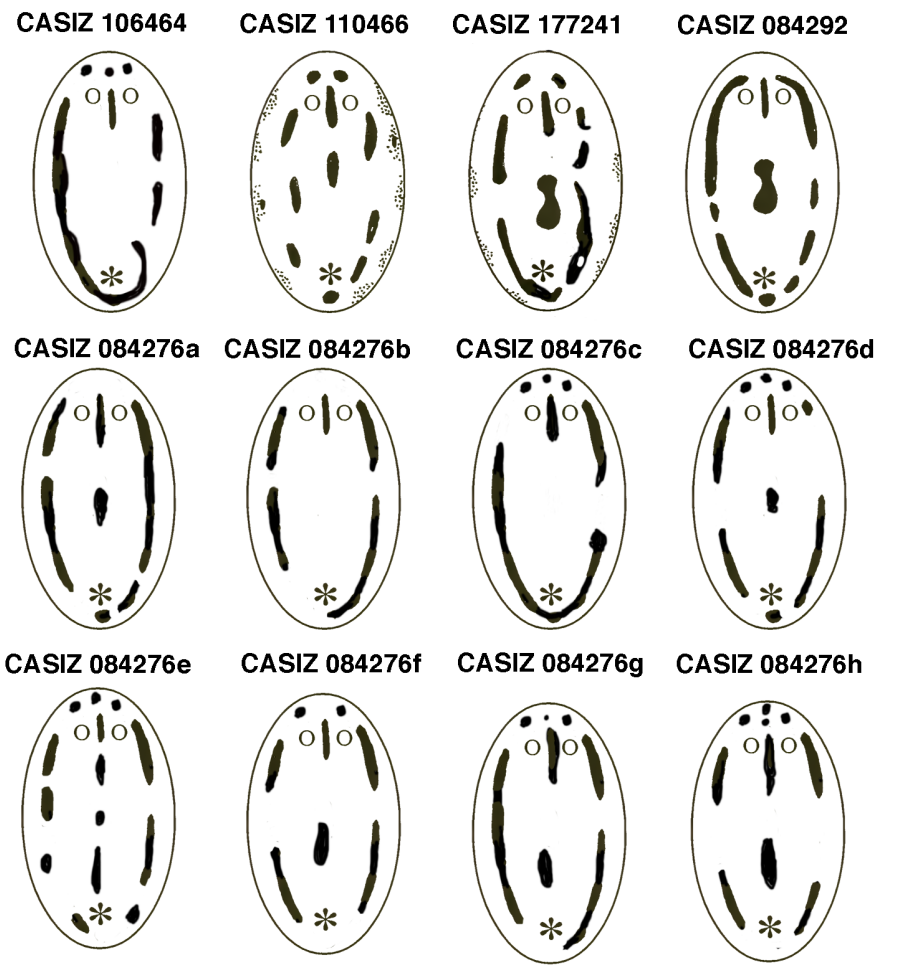

Figure 3. Chromodoris dianae Gosliner \& Behrens, 1998, color patterns.

narrows proximally and divides into a short oviduct and an elongate vas deferens. The distal portion of the vas deferens is wide, convoluted, and prostatic and consists of one major loop that traverses over the surface of the bursa copulatrix. The prostatic portion narrows proximally and transitions into the short muscular ejaculatory segment. This segment expands into the wider penial bulb, which also joins with the distal end of the vagina. The vagina is relatively short and curved and enters the base of the thin-walled, spherical bursa copulatrix. Also, joining at the base of the bursa is the receptaculum duct, which connects with the pyriform curved receptaculum seminis. Along the length of the receptaculum duct is the short branch of the uterine duct that enters the female gland mass. In CASIZ 083686a, the uterine duct passes underneath the receptaculum seminis and enters the female gland mass. This is indicated in Fig. $4 \mathrm{c}$ by a dotted line for the distal portion of the duct. The female gland mass is composed of a small albumen and membrane glands and a larger mucous gland. An obvious vestibular gland is found at the base of the female gland mass near the genital atrium.

\section{Remarks}

When Gosliner \& Behrens (1998) described Chromodoris dianae, they noted considerable variation in morphology, but could not find distinct differences based on the variability. This consideration of a single highly variable species continued in most field identification guides up until 2018 (Gosliner et al., 2008; Gosliner et al., 2015).

Layton et al. (2018) in their analysis of the molecular phylogeny of Chromodoris, discovered numerous cryptic species, including two distinct species referred to as $C$. dianae and $C$. cf. dianae, suggesting that the specimens described by Gosliner \& Behrens (1998) contained more than a single species. This prompted Gosliner et al. (2018), to separate $C$. dianae and Chromodoris sp. 7 in their updated field guide. This study also prompted the more detailed analysis of these two putative species to determine morphological differences between these species, including re-examination of the holotype and paratype material of $C$. dianae and to determine whether the molecular differences found by Layton et al. (2018) correlated with the morphological ones found here. All of the type material, regardless of preservative, still retains the prominent black pigment on the dorsal and lateral surfaces of the body. The holotype of $C$. dianae (CASIZ 106464) clearly has three black spots clearly visible on the anterior portion of the head and a largely continuous black line on the left-hand side of the body (Fig. 3, upper left specimen). This holotype was fixed in Bouin's

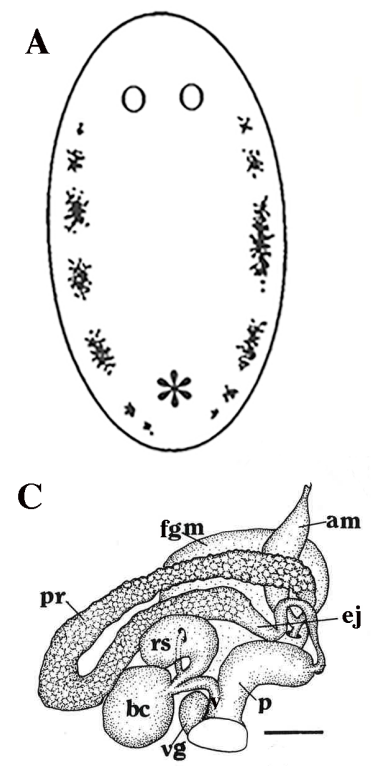

B

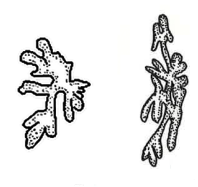

D

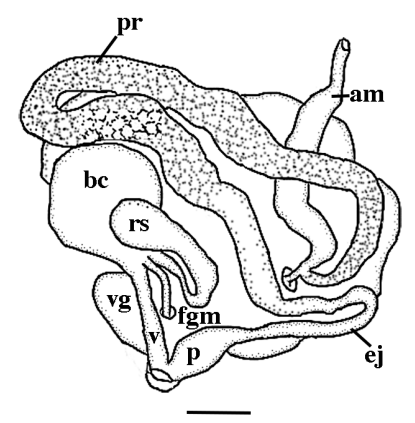

Figure 4. Chromodoris alcalai n. sp., Internal anatomy. a. Distribution of mantle glands, CASIZ 083686a. b. Detail of mantle gland ramification, CASIZ 083686b, 083686a, scale $=1.0 \mathrm{~mm}$. c. Reproductive system CASIZ 083686a, d. CASIZ 083686b. Figure legends: am $=$ ampulla, $b c=$ bursa copulatrix, ej $=$ ejaculatory duct, fgm $=$ female gland mass, $\mathrm{p}=$ penis, $\mathrm{pr}=$ prostatic portion of vas deferens, $r s=$ receptaculum seminis, $u d=$ uterine duct, $v=$ vagina, $v g$ = vestibular gland, scales $=0.5 \mathrm{~mm}$. 
A

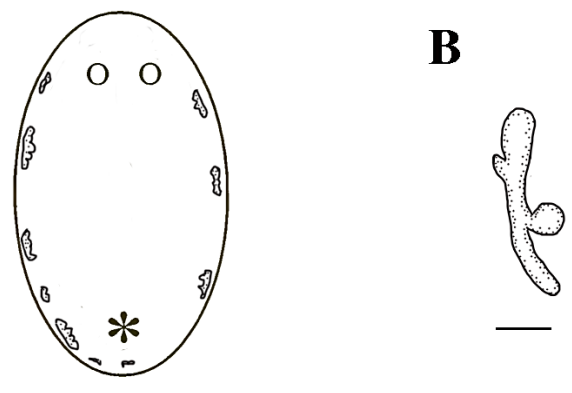

C

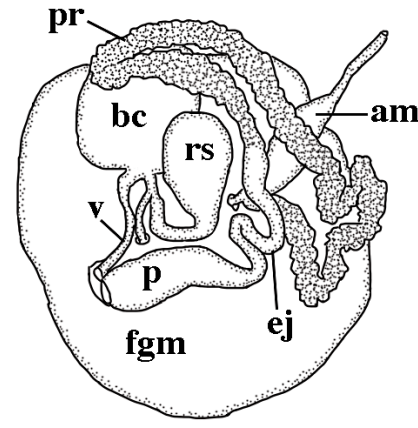

Figure 5. Chromodoris dianae Gosliner \& Behrens, 1998. Internal anatomy. a. Distribution of mantle glands, CASIZ 086002. b. Individual mantle gland, CASIZ 182289, scale $=0.3 \mathrm{~mm}$. c. Reproductive system, CASIZ 086002, am = ampulla, bc = bursa copulatrix, ej $=$ ejaculatory duct, fgm $=$ female gland mass, $p=$ penis, $\mathrm{pr}=$ prostatic portion of vas deferens, $\mathrm{rs}=$ receptaculum seminis, $\mathrm{ud}=$ uterine duct, $\mathrm{v}=$ vagina, $\mathrm{vg}=$ vestibular gland, scale $=0.5 \mathrm{~mm}$.

fixative and thus cannot be sequenced. The specimens are clearly divisible into two distinct groups with different color patterns based on both color patterns of living and preserved animals. The holotype of $C$. dianae and a series of other specimens (Figs. 1e-h, Fig. 3) generally have black spots on the head but always lack a black anterior arch in front of the rhinophores that is present in all specimens of the other species that is here described as C. alcalai (Figs. 1a-d, Fig. 2). Thus, the specimens identified as $C$. cf. dianae by Layton et al. (2018) (CASIZ 182289, CASIZ 177241, CASIZ 200677, WAMS 67532, WAMS 67592, WAMS 67536, WAMS 67531 and Gosliner et al. (2018) actually represent the true C. dianae. A specimen studied previously by Johnson \& Gosliner (2012) (CASIZ 158686) was identified by Layton et al. (2018) as $C$. dianae GB and was originally identified as $C$. dianae by Johnson \& Gosliner (2012). This specimen forms a clade with CASIZ 182289, CASIZ 177241, CASIZ 200677, WAMS 67532, WAMS 67592, WAMS 67536, WAMS 67531 and together they represent the true $C$. dianae. Conversely, specimens identified by Layton et al. (2018) as C. dianae (CASIZ 177242, WAMS 67533, WAMS 67534) actually represent the new species, $C$. alcalai and one of these (CAS177242, now NMP 041295) was thus chosen as the holotype of this species and is illustrated in Fig. 1a. The specimens illustrated as $C$. dianae by Gosliner et al. (2018) are actually C. alcalai and the specimens identified as Chromodoris sp. 7 are actually $C$. dianae. The selection of the holotype of $C$. alcalai was made specifically to link molecular and morphological data and thus avoid any future confusion regarding these two species.

Chromodoris alcalai and $C$. dianae can be readily distinguished based on preserved and living specimens. In living animals, C. alcalai is white to light blue with a distinct marginal white band. The black markings include an anterior arch of black pigment with two pairs of black lines (an anterior pair and posterior pair) that are never continuous. A single exception to the presence of the anterior arch was found in one specimen from Sulawesi, Indonesia (WASMS 677533) (Layton et al., 2018, Fig. S2). Despite this anomaly, the anterior arch was found in the remaining 25 specimens observed here. Additionally, WAMS 677533 shares the remaining distinguishing color characteristics and spiral gill that follow with other specimens of $C$. alcalai as well as bearing 10 gill
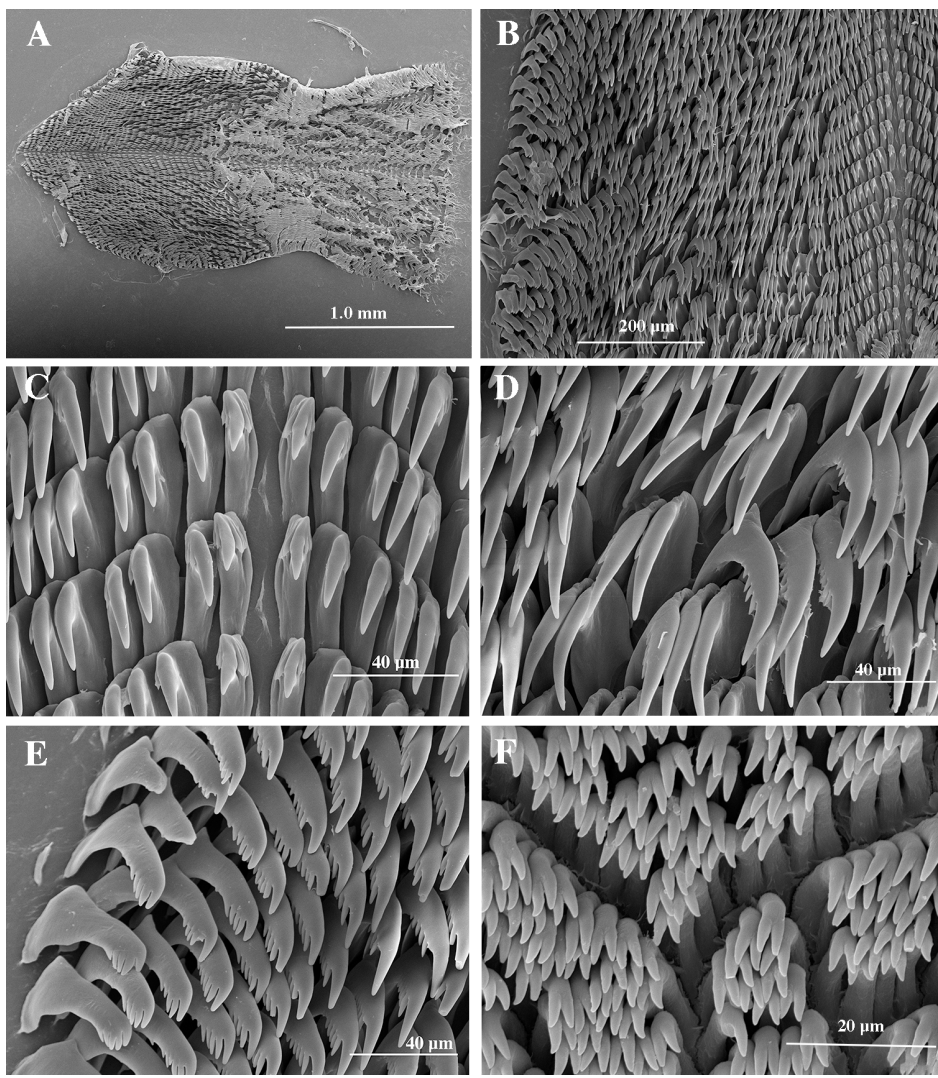

Figure 6. Chromodoris alcalai n. sp. Scanning electron microscope images of jaws and radula, CASIZ 083686b. a. Entire radula. b. Half of radula. c. Rachis of radula. d. Middle lateral teeth. e. Outer lateral teeth. f. Jaw rodlets. 

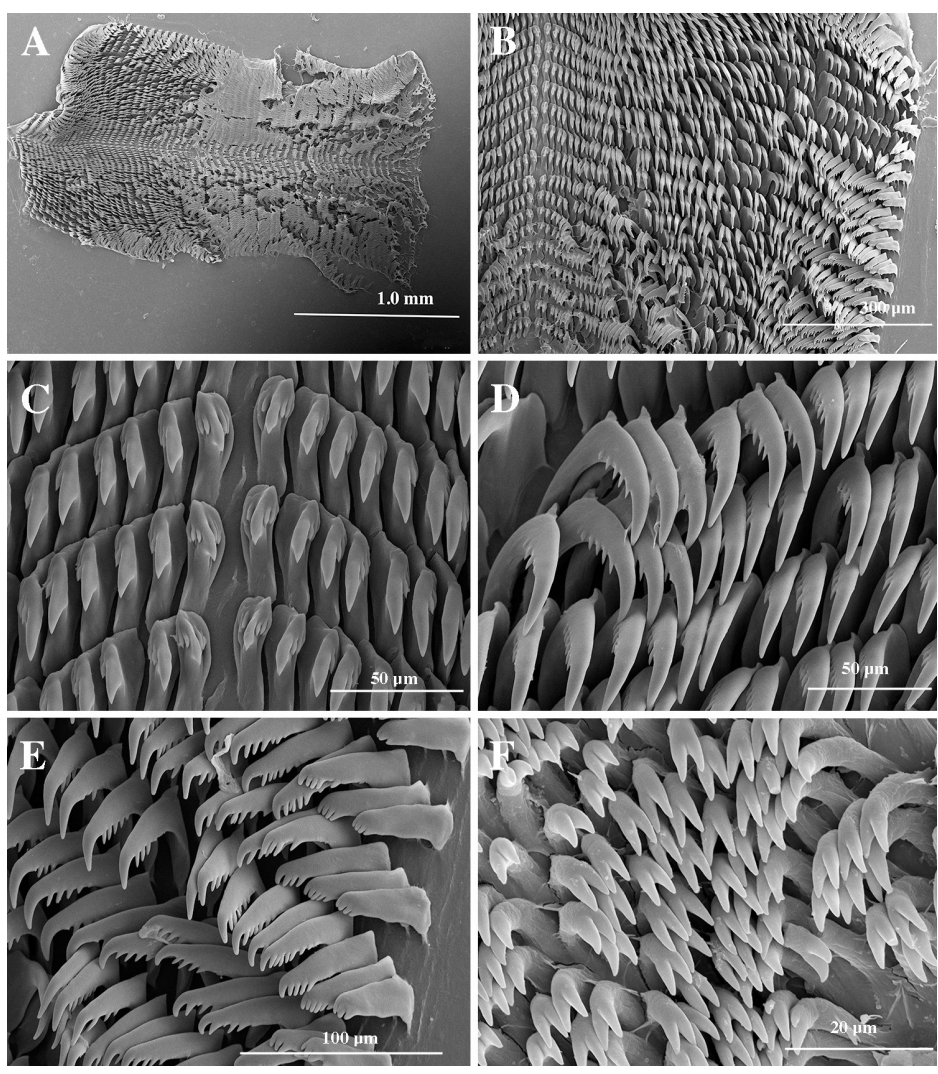

Figure 7. Chromodoris dianae Gosliner \& Behrens, 1998. Scanning electron microscope images of jaws and radula. a. Entire radula, CASIZ 086002. b. Half of radula, CASIZ 086002. c. Rachis of radula, CASIZ 086002. d. Middle lateral teeth, CASIZ 086002. e. Outer lateral teeth, CASIZ 086002. f. Jaw rodlets, CASIZ 177241.

branches, also consistent with $C$. alcalai. The white pigment is represented as distinct spots on the dorsum (Fig. 8a). The gill branches, which number 8-17, form a distinct double spiral (Fig. 8a) as is often found in members of the genera Glossodoris and Doriprismatica (see Matsuda \& Gosliner, 2018) and the base of the gill branches are white with an orange outer half. The interior gill branches forming the spiral are smaller than the outer branches. In contrast, $C$. dianae is white or pale blue with black spots rather than an arch on the head. The lateral black lines can be continuous or discontinuous. Orange marginal spots may be either present or absent around the mantle margin and the white margin is less obvious and more diffuse. The opaque white spotting actually consists of a fine network of opaque white lines with distinct clear spaces between them (Fig. 8b). The 7-9 gill branches form a complete circle (Fig. 8b) rather than a double spiral and are more elongate, often having dark brown or black pigment at the base and orange pigment along the entire outer surface of each branch. The inner surface has opaque white spotting. While there is some overlap in gill branch number, this overlap is less than it appears. Seventeen individuals of both species were
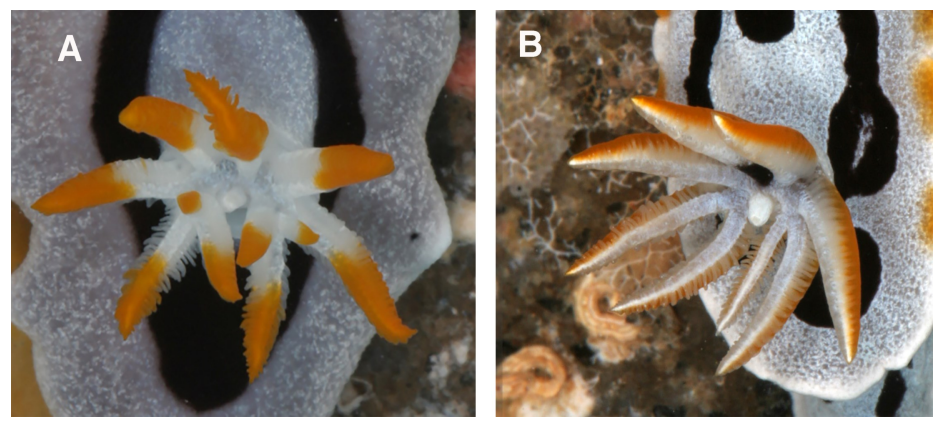

Figure 8. Detail of gill morphology and dorsal opaque white spotting a. Chromodoris alcalai n. sp., Holotype, NMP 041295, Kirby's Rock, Tingloy, Batangas, Philippines. b. Chromodoris dianae Gosliner \& Behrens, 1998, CASIZ 177241, Kirby's Rock, Tingloy, Batangas, Philippines.

examined and there is an average of 11.8 gill branches in $C$. alcalai and 7.8 in $C$. dianae. The only two specimens of $C$. alcalai that had eight (CASIZ 076288) or nine (CASIZ 176654) gill branches were juveniles, less than $15 \mathrm{~mm}$ preserved length. All the remaining specimens had 11-17 branches. No specimens of $C$. dianae had more than 9 gill branches.

There are differences in the mantle glands between the two species, although they are similar in distribution. The glands of C. alcalai are highly ramified (Fig. 4b), whereas they are far less ramified in C. dianae (Fig. 5 b). There is little difference in the shape of the buccal mass and oral tube or in the radular formula and tooth shape (Figs. 6,7) between the two species. In $C$. alcalai, the inner lateral tooth is narrower with coarser denticles than in C. dianae, but this difference is very minor. Similarly, there are few reproductive differences between the two species except that the prostatic portion of the vas deferens of $C$. alcalai has a simple loop (Figs. 4c, d) whereas it is more convoluted in C. dianae (Fig. 5c).

Consistent morphological differences permit easy differentiation of C. alcalai and C. dianae. More careful and thorough examination of specimens now permits us to unambiguously distinguish these two species based on morphological characters in addition to the molecular markers previously employed. Strong correlation between a suite of morphological features outlined above with the molecular differences found by Layton et al. (2018) consistently permits our ability to distinguish living and preserved specimens of $C$. dianae and C. alcalai. Hopefully, these features will prevent future confusion surrounding the checkered taxonomic history of these two species.

\section{Discussion}

Recent molecular studies by Layton et al. (2018) revealed that the species diversity of Chromodoris is much greater than 
previously thought, based on morphological studies. Previously, 22 species of Chromodoris were recognized and Layton et al. (2018) found 39 species lineages. Tibiriçá et al. (2020) found 7 distinct lineages of Chromodoris present in East Africa, including one not found by Layton et al. (2018). Bonomo \& Gosliner (2020) sequenced additional specimens and found 44 distinct species lineages in Chromodoris, indicating that even more hidden diversity is found in the genus. It has been shown that the Philippine waters are among the richest in the ocean. Here we found that the Philippine Islands are inhabited by at least 18 species of Chromodoris, roughly $41 \%$ of the global biodiversity of Chromodoris, thus reinforcing the species richness present in the region. This is identical to the findings of Ong et al. (2017), where $41 \%$ of the global biodiversity of Gastropteridae was found in the Verde Island Passage of the Philippines. The 18 species of Chromodoris known from the Philippines include: C. alcalai Gosliner, 2020, C. annae Bergh, 1877, C. aspersa (Gould, 1852), C. balat Bonomo \& Gosliner, 2020, C. colemani Rudman, 1982, C. dianae Gosliner \& Behrens, 1998, C. elisabethina Bergh, 1877, C. kalawakan Bonomo \& Gosliner, 2020, C. lineolata (van Hasselt, 1824), C. lochi Rudman, 1982, C. magnifica (Quoy \& Gaimard, 1832), C. michaeli Gosliner \& Behrens, 1998, C. quagga Bonomo \& Gosliner, 2020, C. striatella Bergh, 1877, C. strigata Rudman, 1982, C. willani Rudman, 1982, C. sp. and C. sp. aff. mandapamensis.

Layton et al. (2018) suggested that of the 39 species lineages of Chromodoris recognized and found by molecular phylogenetics only five were considered to have stable color patterns that were easily recognized. More recently, Bonomo \& Gosliner (2020) found that they were able to recognize distinct color patterns for the four new species they described and three of these were species included in Layton et al. (2018). Several of the color patterns they recognized had very small sample sizes and need to be tested with larger population numbers to confirm that the range of variation still permits finding unique color patterns for each of these species. One of the species they discussed had a large number of specimens and stable color patterns for this species to be easily identifiable. Chromodoris dianae and Chromodoris cf. dianae (described here as $C$. alcalai) were both included in Layton et al. (2018), as examples of species that lacked stable color patterns and are difficult to distinguish. Clearly, distinguishing those species was indeed problematic given the confusion surrounding their taxonomy and that they were confused as a single species. However, the present study, where a large number of individuals of both species could be compared, revealed that despite the variability found in the color patterns of both species, consistent differences in color pattern and gill arrangement made discrimination of the two species rather easy. In this case, all that was necessary to differentiate similarly appearing species was more careful examination of a large number of specimens.

Gosliner \& Behrens (1998) studied the arrangement of mantle glands in several species of Chromodoris and concluded that the arrangement of mantle gland distribution was useful in differentiating species of this genus. Wilson and Willan (2007) examined variation in mantle gland distribution in Chromodoris willani. They found that more variation was found within this species than had been indicated by Gosliner \& Behrens (1998) and concluded that mantle gland distribution was more likely useful in differentiating genera than it was in separating species. In the examination of large numbers (more than 17 individuals of each species) of C. alcalai and C. dianae in the present study, we found consistent differences in the shape of the mantle glands as well as their distribution. Specifically, all of the specimens of $C$. alcalai had a denser distribution of mantle glands and the individual glands were much more highly ramified than were those of $C$. dianae (Figs. $4 \mathrm{~b}, 5 \mathrm{~b}$ ). Certainly, more studies are needed to examine variation of mantle gland shape and distribution within and between species of Chromodoris to determine the extent to which species-specific differences can be useful in differentiating species. However, it is evident that the taxonomic utility of this character was too readily discounted by some previous studies.

\section{Conclusions}

Taxonomic confusion has surrounded the differentiation of various species of chromodorid nudibranchs and the discovery of numerous previously undetected, distinct lineages by molecular phylogenetic methods has created an even greater challenge. However, this study clearly shows that detailed morphological characters, when combined with molecular studies, provide an even more robust understanding of species boundaries and reveals a wealth of characters that can be used to differentiate species. Molecular methods are clearly the best way to reveal cryptic lineages, but that morphology provides a powerful partner in producing an understanding of convergent and divergent evolution patterns. Any key component is that understanding the evolutionary foundation of color patterns provides novel insights into the evolution of mimicry and aposematic color patterns in this clade of brightly colored nudibranchs.

\section{Acknowledgements}

This research was supported by a grant from National Science Foundation: DEB 1257630 grant to Terrence Gosliner, 
Kent Carpenter, Richard Mooi, Luiz Rocha and Gary Williams. This collaborative research involved the following partners in the Philippines: former Secretary of Agriculture Proceso J. Alcala; former Philippine Consul General Marciano Paynor and the consular staff in San Francisco; former Bureau of Fisheries and Aquatic Resources (BFAR) Director Attorney Asis G. Perez; BFAR colleagues, especially Attorney Analiza Vitug, Ludivina Labe; National Fisheries and Research Development Institute (NFRDI) colleagues, especially Director Drusila Bayate and November Romena; U.S. Embassy staff, especially Heath Bailey, Richard Bakewell and Maria Theresa N. Villa; staff of the Department of Foreign Affairs; University of the Philippines (UP) administrators and colleagues including former UP President Alfredo Pascual, former Vice President Giselle Concepción, Dr Annette Meñez; the staff of the National Museum of the Philippines, especially Dr Jeremy Barns, Anna Labrador and Marivene Manuel Santos. We also thank Boy Venus, Joy Napeñas, Peri Paleracio, Alexis Principe, the staff of Atlantis Dive Resort Puerto Galera (especially Gordon Strahan, Andy Pope, Marco Inocencio, Stephen Lamont, P.J Aristorenas), Kati Escheweiler and the wonderful staff of the 3P Resort in Romblon, Philippines. Ipat Luna, Anne Hazel Javier, Jay-o Castillo, Arvel Malubag and Mary Lou Salcedo. Lastly, our sincere thanks are extended to our fellow Academy and Filipino teammates on the expeditions. All the specimens from the Philippines were collected under our Gratuitous Permits (GP-0077-14, GP-0085-15) from the shallow waters of the municipalities of Mabini, Tingloy, Calatagan and Puerto Galera. This is part of the joint Department of Agriculture-NFRDI-California Academy of Sciences Memorandum of Agreement for the ongoing implementation of the National Science Foundation-funded biodiversity expedition in the Verde Island Passage. The specimens were collected in accordance with the terms and conditions of the gratuitous permit and under the supervision of our partners from BFAR Fisheries Regulatory and Quarantine Division and NFRDI. I greatly appreciate and acknowledge the collaborative work undertaken with my colleagues Kara Layton and Nerida Wilson that provided the molecular framework that led to many of the insights into species boundaries that allowed this work to be undertaken.

\section{Literature cited}

Bonomo, L.J. \& T.M. Gosliner, 2020. Adding stars to the Chromodoris(Nudibranchia: Chromodorididae) galaxy with the description of four new species. Zootaxa, 4819(3): 401435.

Epstein, H., J. Hallas, R.F. Johnson, A. Lopez \& T.M. Gosliner,
2018. Reading between the lines: Revealing cryptic species diversity and colour patterns in Hypselodoris nudibranchs (Mollusca: Heterobranchia: Chromodorididae). Zoological Journal of the Linnean Society, 186: 116-189.

Gosliner, T.M. \& D.W. Behrens, 1998. Five new species of Chromodoris (Mollusca: Nudibranchia: Chromodorididae) from the tropical Indo-Pacific Ocean. Proceedings of the California Academy of Sciences, 50(5): 139-165.

Gosliner, T.M., D.W. Behrens \& Á. Valdés, 2008. Indo-Pacific nudibranchs and sea slugs: a field guide to the world's most diverse fauna. Sea Challengers/California Academy of Sciences, Gig Harbor/San Francisco, U.S.A., 426 pp.

Gosliner, T., Á. Valdés \& D.W. Behrens, 2015. Nudibranch \& sea slug identification Indo-Pacific. First edition. New World Publications, Jacksonville, U.S.A., 408 pp.

Gosliner, T.M., Á. Valdés, Á. \& D.W. Behrens, 2018. Nudibranch \& sea slug identification Indo-Pacific. Second edition. New World Publications, Jacksonville, U.S.A., 451 pp.

Johnson, R. \& T. Gosliner, 2012. Traditional taxonomic groupings mask evolutionary history: a molecular phylogeny and new classification of the chromodorid nudibranchs. PLoS One, 7(4): e33479. doi:10.1371/ journal.pone.0033479

Layton, K.K.S, T.M. Gosliner \& N.G. Wilson, 2018. Species delimitation and molecular phylogeny of Indo-Pacific Chromodoris nudibranch slugs (Doridina: Chromodorididae) Molecular Phylogenetics and Evolution, 124: 27-36.

Matsuda, S. \& T.M. Gosliner, 2018. Glossing over cryptic species: descriptions of four cryptic and pseudocryptic species of Glossodoris and three new species of Doriprismatica (Nudibranchia: Chromodorididae), Zootaxa, 4444 (3): 501-529.

Ong, E., J. Hallas \& T. Gosliner, 2017. Like a bat out of heaven: the phylogeny and diversity of the bat-winged slugs (Heterobranchia: Gastropteridae). Zoological Journal of the Linnean Society, 180(4): 755-789.

Tibiriçá, Y., M. Pola, D. Ortigosa \& J.L. Cervera, 2020. Systematic review of the "Chromodoris quadricolor group" of East Africa, with descriptions of two new species of the genus Chromodoris Alder \& Hancock, 1855 (Heterobranchia, Nudibranchia). Journal of Zoological Systematics and Evolutionary Research, 58: 1-32. https:// doi.org/10.1111/jzs.12334

Turner, L.M. \& N.G. Wilson, 2008. Polyphyly across oceans: a molecular phylogeny of the Chromodorididae (Mollusca, Nudibranchia). Zoologica Scripta, 37: 23-42.

Wilson, N.G. \& M.S.Y. Lee, 2005. Molecular phylogeny of 
Chromodoris (Mollusca, Nudibranchia) and the identification of a planar spawning clade. Molecular Phylogenetics and Evolution, 36: 722-727.

Wilson, N. G. \& R. C. Willan, 2007. Hypselodoris jacksoni, a new species from the south-western Pacific Ocean (Nudibranchia: Chromodorididae), with a discussion on intraspecific variation in mantle glands in Chromodoris willani Rudman, 1982. Zootaxa, 1549: 29-42 